ВІСНИК

ОДЕСЬКОГО НАЦІОНАЛЬНОГО

МОРСЬКОГО УНІВЕРСИТЕТУ

№ 3 (63), 2020
HERALD

OF THE ODESSA NATIONAL

MARITIME UNIVERSITY № 3 (63), 2020

УДК 93/94:351.81:37.046(477.74)

DOI 10.33082/2226-1893-2020-3-5-20

\title{
ПЕРИПЕТИИ СУДЬБЫ ПРОФЕССОРА ЧАРЛЬЗА КЛАРКА: К ИСТОРИИ «ОДЕССКОГО» ПЕРИОДА ЖИЗНИ. Ч. 2
}

\author{
В.В. Левченко
}

к.и.н., доцент кафедры

«Украиноведение, историко-правовые и языковые дисциплины»

Одесский наџиональньй морской университет

Г.С. Левченко

к.и.н., доцент кафедры «История Украины»

Одесский национальный университет имени И.И. Мечникова

А.Б. Ляшенко

к.т.н., профессор, декан факультета судостроения, информационных технологий и системотехники

Одесский наџиональный морской университет

Аннотация. Во второй части статьи, посвященной профессору Ч.Д. Кларку, указано, что изучение истории становления выстего политехнического образования в Одессе на рубеже 1910-х-1920-х г2., когда ученый был на вершине своей административной карьеры в системе высшего образования, являлся не только членом академического сообщества, но и долгое время сам его возглавлял, невозможно без обращения к исследованию характеристики его повседневной жизни.

Осуществлена попытка соединить изучение повседневной жизни Ч.Д. Кларка и истории функиионирования академического сообщества выстей школь Одессы в начале 1920-х г2. С одной стороны, выбор фигуры Ч.Д. Кларка определяется тем, что его судьба представляет существенный интерес, так как он являлся неформальным лидером Одесского политехнического института и высшей школь Одессы. В период, когда он был председателем Одесского отделения Всеукраинского комитета содействия ученым академическое сообщество переживало наиболее драматические события истории 1920-х г2. С другой стороны, карьерный путь Ч.Д. Кларка являлся в некотором смысле показательным для тех ученых, кому доводилось одновременно совмещать научную и административную сферы деятельности. В то же время Ч.Д. Кларк прошел все основные стадии как научного, так и административного роста, поэтому на его примере хорошо видно, из каких составляющих складывалась потенциальная карьера ученого в академическом сообществе.

(С Левченко В.В., Левченко Г.С., Ляшенко А.Б., 2020 
ВІСНИК

ОДЕСЬКОГО НАЦІОНАЛЬНОГО

МОРСЬКОГО УНІВЕРСИТЕТУ

№ 3 (63), 2020
HERALD

OF THE ODESSA NATIONAL

MARITIME UNIVERSITY

№ 3 (63), 2020

Изучение персоны Ч.Д. Кларка дало возможность восполнить до сих пор существующий в историографии пробел, наличие которого все еще не позволяет составить ясное представление о нем как об ученом, педагоге, администраторе, организаторе науки, общественном деятеле и гражданине, что повышиет значимость данного исследования. Осущеествлена попытка раскрытия принципиальных взглядов ученого на развитие исторических событий того времени.

Ключевые слова: Ч.Д. Кларк, Одеса, повседневная жизнь, высшая школа, академическое сообщество.

УДК 93/94:351.81:37.046(477.74)

DOI 10.33082/2226-1893-2020-3-5-20

\title{
ПЕРИПЕТІЇ ДОЛІ ПРОФЕСОРА ЧАРЛЬЗА КЛАРКА: ДО ІСТОРІЇ «ОДЕСЬКОГО» ПЕРІОДУ ЖИТТЯ. Ч. 2
}

\author{
В.В. Левченко \\ к.і.н., доцент кафедри \\ «Українознавство, історико-правові та мовні дисципліни» \\ Одеський національний морський університет \\ Г.С. Левченко \\ к.і.н., доцент кафедри «Історія України» \\ Одеський національний університет імені I.I. Мечникова \\ О.Б. Ляшенко \\ к.т.н., професор, декан факультету суднобудування, \\ інформаційних технологій і системотехніки \\ Одеський національний морський університет
}

Анотація: У другій частині статті, присвяченій професору Ч.Д. Кларку, зазначено, щзо вивчення історії становлення вищзӧ політехнічної освіти в Одесі на рубежі 1910-х-1920-х рр., коли вчений був на вершині своєї адміністративної кар'єри в системі вищзої освіти, був не тільки членом академічної спільноти, а й довгий час сам ї̈ очолювув, неможливо без звернення до дослідження характеристики його повсякденного життя.

Здійснено спробу поєднати вивчення повсякденного життя Ч.Д. Кларка та історії функціонування академічної спільноти вищої школи Одеси на початку 1920-х рр. 3 одного боку, вибір фігури Ч.Д. Кларка визначається тим, щзо його доля представляє істотний інтерес, так як він був неформальним лідером Одеського політехнічного інституту та вищзӧ школи Одеси. У період, коли він був головою Одеського відділення Всеукраїнського комітету сприяння вченим акаде- 
мічне співтовариство переживало найбільш драматичні події історії 1920-х рр. 3 іншого боку, кар'єрний шлях Ч.Д. Кларка був в деякому сенсі показовим для тих вчених, кому доводилося одночасно поєднувати наукову та адміністративну сфери діяльності. У той же час Ч.Д. Кларк пройшов всі основні стадії як наукового, так й адміністративного зростання, тому на його прикладі добре видно, з яких моментів складалася потенційна кар'єра вченого в академічній спільноті. Вивчення персони Ч.Д. Кларка дало можливість заповнити досі існуючий в історіографії пробіл, наявність якого все ще не дозволяє скласти чітке уявлення про нього як про вченого, педагога, адміністратора, організатора науки, громадського діяча і громадянина, щзо підвищує значущість даного дослідження. Здійснено спробу розкриття принщипових поглядів вченого на розвиток історичних подій того часу.

Ключові слова: Ч.Д. Кларк, Одеса, повсякденне життя, вищъа школа, академічне товариство.

UDC 93/94:351.81:37.046(477.74)

DOI 10.33082/2226-1893-2020-3-5-20

THE PERIPETIES OF PROFESSOR CHARLES CLARK: TO THE HISTORY OF THE «ODESSA» PERIOD OF LIFE. PART 2

\author{
Valery Levchenko \\ PhD, docent Department of Ukrainian Studies, Historical, \\ Legal and Language Disciplines \\ Odessa National Maritime University \\ Galina Levchenko \\ $\mathrm{PhD}$, docent Department of History of Ukraine \\ Odessa National University named after I.I. Mechnikov \\ Alexander Lyashenko \\ PhD, professor, Dean of the Faculty of Shipbuilding, \\ Information Technology and System Engineering \\ Odessa National Maritime University
}

Abstract. In the second part of the article dedicated to Professor Ch. Clark, it is indicated that the study of the history of the formation of higher polytechnic education in Odessa at the turn of the 1910s-1920s, when the scientist was at the top of his administrative career in the higher education system, was not only a member of the academic community, but also for a long time led him, it is impossible without recourse to the study of the characteristics of his personality.

An attempt was made to combine the study of the biography of Ch. Clarke and the history of the functioning of the academic community of higher education in Odessa in the early 1920s. On the one hand, the choice of 
the figure Ch. Clarke is determined by the fact that his fate is of significant interest, since he was the informal leader of the Odessa Polytechnic Institute and the higher school of Odessa. During the period when he was chairman of the Odessa branch of the All-Ukrainian Committee for Assistance to Scientists, the academic community experienced the most dramatic events in the history of the 1920s. On the other hand, the career path of Ch. Clarke was, in a sense, indicative of those scientists who happened to simultaneously combine scientific and administrative spheres of activity. At the same time, Ch. Clark went through all the main stages of both scientific and administrative growth, therefore, his example clearly shows what constitutes a potential career as a scientist in the academic community. Studying the person Ch. Clarke made it possible to fill the gap that still exists in historiography, the presence of which still does not allow one to form a clear idea of him as a scientist, teacher, administrator, organizer of science, public figure and citizen, which increases the significance of this study. An attempt was made to reveal the principal views of the scientist on the development of historical events of that time.

Keywords: Ch. Clarke, Odessa, daily life, high school, academic community.

Из истории общественной деятельности и повседневной жизни Ч.Д. Кларка в Одессе. Историческое изучение академического сообщества можно объяснить необходимостью более глубокого понимания этого сообщества, особенностей его функционирования и деятельности в нем отдельного человека. Условия, в которых приходилось существовать научному сообществу в Одессе, за последние сто лет несколько раз менялись. Однако нельзя не признать, что между академическим сообществом периода на рубеже 1910-х-1920-х гг. и современным существует определенная преемственность в том, что касается его организации, потребностей, ценностных установок, взаимоотношений с властями. Таким образом, представляется, что роль академической корпорации в современной общественно-политической жизни не может быть понята иначе, кроме как изучения через призму его исторического развития.

В поле зрения историографов попадают как концепции ученых, так и модели социального поведения, структуры и процессы, задающие условия творческой деятельности и определяющие организацию научной жизни. Феномен возрастающего интереса к проблемам повседневной жизни научного сообщества вписывается в антропологический поворот современной историографии. Эти новации заметны и в отечественной науке. Особое место в этих исследованиях занимает и сам ученый, его «жизненный мир», его идеалы, социокультурная среда и повседневность, оказывающие влияние на их формирование. В связи с этим повседневная жизнь профессиональных научных сообществ и его отдельных представителей становятся предметом усиленного научного внимания. 
ВІСНИК

ОДЕСЬКОГО НАЦІОНАЛЬНОГО

МОРСЬКОГО УНІВЕРСИТЕТУ № 3 (63), 2020
HERALD

OF THE ODESSA NATIONAL

MARITIME UNIVERSITY № 3 (63), 2020

Предметом научного анализа являются принятые в академической корпорации нормы поведения, связанные с непосредственным содержанием научной деятельности и разными составляющими повседневной жизни, коммуникативными взаимоотношениями ученых, регулированием научной деятельности со стороны общества и государства и т. п. Главный аспект изучения повседневной жизни предполагает анализ представлений ученых о социальной роли в жизни науки. Хотя повседневная жизнь ученого в качестве основного компонента включает моральные качества, все же она определяется не столько особенностями научного труда, сколько принадлежностью академического сообщества к такому социальному сегменту, как научная интеллигенция. Не исключением всех подобных составляющей повседневной жизни представителей академического сообщества является и Ч.Д. Кларк.

В «одесский» период жизни Ч.Д. Кларка необходимо обратить внимание на проведение им объемной и продуктивной общественной работы. Он являлся членом многих общественных организаций: членом профессионального союза советских работников с 1920 г. (билет № 2871), почетным членом Пленума Одесского губернского комитета профессионально-технического и специально-научного образования [1, л. 133], председателем Технического совета Одесского губернского советского народного хозяйства [2, л. 169; 3, л. 9], председателем Технического совещания Общества для классификации судов «Русскласс», председателем Комиссии по электрификации юга при Техническом обществе, членом Высшего технического совета при Одесском губернском коммунальном отделе и других обществ, союзов и объединений [1, л. 136 об.].

Такая активная и плодотворная общественная деятельность Ч.Д. Кларка была отмечена одесской городской властью. В начале 1920-х гг. решением Одесского городского совета улице, на которой находился ОПИ, а сегодня находится Одесский национальный морской университет, было присвоено имя профессора Ч.Д. Кларка (до того улица называлась Внешняя, ныне улица имени И.И. Мечникова) [4].

Продуктивная разноплановая деятельность Ч.Д. Кларка во многих сферах жизни требовала от ученого затрат на большое количество времени, повышенных физических и духовных сил, что во многом зависело от условий его повседневной жизни. Характеризуя будничную жизнь Ч.Д. Кларка на фоне общих условий быта преподавательского состава ОПИ, как и в целом всей высшей школы Одессы, надо сказать, что в результате Первой мировой войны, революционных событий 1917 г. и Гражданской войны материальное положение всех его представителей было чрезвычайно затруднительным.

На рубеже 1910-х-1920-х гг. благосостояние большинства представителей преподавательского состава ОПИ состояло из заработной платы, академического пайка и дополнительного академического обеспечения. Очень часто разные виды материального снабжения выдавались не регу- 
лярно и с опозданием, при этом на фоне прогрессирующей инфляции и стагнации. Если размер зарплаты преподавателей контролировался НКП УССР, то за другие статьи материального обеспечения ученых (академические пайки, академическое обеспечение и т. п.) ответственность несли Всеукраинский комитет содействия ученым и Секция научных работников СССР.

Осознавая необходимость сохранения научно-педагогического потенциала, руководство страны создало две вышеупомянутые общественные организации, основной задачей которых являлось оказание посильной помощи работникам вузов. Однако принятые в первые годы советской власти декреты относительно материального обеспечения научных работников, неприкосновенности их имущества, улучшение жилищных условий практически не выполнялись из-за ряда объективных причин, первой из которых была хроническая нехватка государственных средств. Поэтому часто их потребности и обращения рассматривались с большим опозданием или просто игнорировались.

Одесское бюро Секции научных работников СССР, чтобы помочь одиноким ученым и повысить их морально-психологическое состояние инициировало создание в ноябре 1922 г. «Дома ученых», который по уставу должен был способствовать организации и развитию научных обществ и ассоциаций в Одесской губернии. Инициативное участие в работе «Дома ученых» принимал и Ч.Д. Кларк, занимая в 1922-1923 гг. должность председателя Одесского отделения Всеукраинского комитета содействия ученым (см. прил. 4 и 5). Исходя из содержания двух впервые репрезентованных архивных документов, можем констатировать об ответственном и скрупулезном отношении Ч.Д. Кларка к порученному ему коллегами исполнению своих обязанностей по распределению материальных ценностей среди представителей научного сообщества Одессы. Избрание Ч.Д. Кларка на такую ответственную должность, как председатель Одесского отделения Всеукраинского комитета содействия ученым, характеризует его как человека, который в одесских академических кругах за менее чем четыре года пребывания в этом окружении, снискал уважение и авторитет среди коллег, которые, несмотря на наличие других авторитетных ученых (А.А. Браунер, Б.В. Варнеке, Э.Я. Немировский, П.И. Петренко-Критченко, Г.И. Танфильев, И.Ю. Тимченко, А.И. Томсон, Д.К. Третьяков, В.П. Филатов, А.Я. Шпаков и др.), именно ему доверили нести ответственность за распределение материальных благ.

В общих чертах охарактеризовав сложное материальное положение представителей одесского научного сообщества, осуществим попытку реконструировать некоторые аспекты повседневного бытия Ч.Д. Кларка в «одесский» период его жизни. Пребывая в Одессе в период с августа 1918 г. до лета 1920 г. Ч.Д. Кларк вместе с семьей жил в квартире № 6 в доме по адресу - улица Гоголя, 6 (здание построено в 1878 г. по проекту русского архитектора польского происхождения Ф.В. Гонсиоровского, 
ВІСНИК

ОДЕСЬКОГО НАЦІОНАЛЬНОГО

МОРСЬКОГО УНІВЕРСИТЕТУ

№ 3 (63), 2020
HERALD

OF THE ODESSA NATIONAL

MARITIME UNIVERSITY № 3 (63), 2020

одного из основателей Одесского отделения Императорского русского технического общества). Согласно архивным данным, по этому же адресу в это же время проживали еще две семьи коллег Ч.Д. Кларка, также появившихся в Одессе в статусе беженцев - профессоров Б.Н. Кандибы (кафедра гидротехники) и М.И. Лисянского (кафедра прикладной механики) [5, л. 46]. Позволим себе предположить, что в условиях Гражданской войны из-за пребывания в Одессе большого количества беженцев и отсутствия свободных жилых площадей, многокомнатная квартира под № 6 в доме на улице Гоголя, 6, была поделена между семьями трех профессоров, приглашенных для работы в ОПИ.

Начиная с 1920/21 учебного года, местом жительства Ч.Д. Кларка и его семьи стало одно из помещений ОПИ по адресу - улица Внешняя, 34. Необходимо сделать отступление и указать, что с установлением в 1920 г. в Одессе советской власти ОПИ был вынужден поменять свое местонахождение. По решению новой власти ОПИ выделили здания, закрытого летом 1920 г. Одесского института императора Николая I (бывший Одесский институт благородных девиц) и расформированного Одесского учебного округа и примыкавшие к ним территории между улицами Внешней (ныне Мечникова) и Балковской. Помещения бывших Сабанских казарм (улица Канатная, 23), где с 1918 г. первоначально размещался ОПИ, в 1920 г. с приходом в Одессу большевиков было занято Одесской губернской чрезвычайной комиссией [6, л. 2 об.]. Во многих документах периода 1920-1923 гг. в графе «место проживания» Ч.Д. Кларк указывал адрес ОПИ - «Внешняя, 34. Здание института» [3, л. 9]. Этот же адрес ученый указывал и в «личном деле», заполненном собственноручно 4 апреля 1923 г. [1, л. 133]. Таким образом, можно констатировать, что в период 1920-1923 гг. профессор вместе с семьей жил в помещении одного из зданий ОПИ.

Период пребывания Ч.Д. Кларка с семьей в Одессе пришелся на сложные годы экономического и материальной кризиса. Катастрофическое материальное положение педагогов руководство НКП УССР в первые годы своей деятельности пыталось улучшить, но постоянно растущая инфляция оставляла для удовлетворения их минимальных потребностей скудные средства. В какой-то степени материальное положение ученых в начале 1920-х гг. улучшали предоставляемые губернской администрацией вещи первой необходимости: продукты, галоши, дрова, керосин и т. п. Например, в сентябре 1918 г. согласно «Ведомости продуктов, потребных для профессоров и служащих Одесского Политехнического института» профессору Ч.Д. Кларку должно было быть выдано 20 фунтов $(\approx 8,2$ кг) галет, 5 коробок мясных консервов, 10 фунтов сахара $(\approx 4,1$ кг) и 5 фунтов $(\approx 2$ кг) свечей [7, л. 20, 45]. В ноябре и декабре 1919 г. Ч.Д. Кларк, равно как и другие его коллеги, получал «Кормовое довольствие», соответственно 1898 руб. 40 коп. и 2559 руб. 67 коп. [8, л. 87, 97]. Материальную помощь со стороны ОПИ 
Ч.Д. Кларк также получал и на членов своей семьи, которая по состоянию на 4 апреля 1923 г. состояла из семи человек - самого ученого, жены, трех сыновей и двух дочерей $[1$, л. 133]. Например, в конце декабря 1920 г. в инициированном Президиумом ОПИ 28 декабря 1920 г. сборе данных о наличии необходимости преподавателей в получении обуви для них и ремонте обуви членов семьи, находящихся на их иждивении, Ч.Д. Кларк указал, что в приобретении обуви нуждается он, а ремонт обуви необходим жене, дочери и сыну [9, л. 94].

Необходимо отметить, что на протяжении всего времени пребывания в Одессе среди всех преподавателей ОПИ Ч.Д. Кларк был самым высокооплачиваемым специалистом. Например, в сентябре 1918 г. его месячный оклад составил 1700 руб. Подобная сумма заработной платы была самой высокой в ОПИ, даже по сравнению с месячным окладом ректора А.А. Нилуса (1 250 руб.) [10, л. 4]. В октябре 1918 г. среди всех преподавателей ОПИ Ч.Д. Кларк также получил самый высокий оклад 2275 руб., который состоял из 700 руб. месячного оклада профессора, 1125 руб. за ведение аудиторных занятий (22,5 часа в неделю), 200 руб. за деканство, 150 руб. за ведение объединенных заседаний и 100 руб. за заведование гидравлической лабораторией. Среди других преподавателей ОПИ подобных зарплат не было ни у кого. Наиболее высокая зарплата среди других коллег Ч.Д. Кларка была у доцента А.И. Дидебулидзе (1583 руб. при аудиторной нагрузке в 20 часов в неделю), профессора А.А. Копылова (1 525 руб., 16,5 часов), доцента К.С. Завриева (1 358 руб., 17 часов), ректора А.А. Нилуса и проректора И.Ю. Тимченко (по 1250 руб.), профессора Л.И. Мандельштама (1 200 руб., 7 часов), профессора К.К. Симинского (1 125 руб., 14,5 часов) и профессора Б.Н. Кандибы (1 050 руб., 7 часов) [10, л. 9-10]. У большинства других преподавателей зарплата преимущественно в среднем равнялась от 100 до 300 руб. Это в первую очередь зависело от того, какую должность занимал специалист - штатную или внештатную (из 55 преподавателей ОПИ, только 14 человек занимали штатные должности), что существенно влияло на общую сумму оклада. В декабре 1918 г. Ч.Д. Кларк получил еще больше увеличенную зарплату - 2425 руб. Тогда как другие его коллеги (за исключением проректора И.Ю. Тимченко, который заработал 1550 руб.) получали жалованье в тех же размерах, как и в предыдущие месяцы [10, л. 35]. Самым высокооплачиваемым преподавателем в ОПИ Ч.Д. Кларк оставался и в последующие месяцы 1918/19 учебного года - в январе и марте 1919 г. он получал зарплату по 2375 руб. [8, л. 57-57 об., 59-59 об.].

Если в 1918/19 учебном году зарплата Ч.Д. Кларка превышала жалованье его ведущих коллег на $\approx 30-100 \%$, то в 1919/20 учебном году она уже была больше на $\approx 200-300 \%$. Например, в сентябре 1919 г. месячный оклад Ч.Д. Кларка равнялся 10300 руб., тогда как оклады других его коллег были в разы меньше: ректора А.А. Нилуса - меньше на 
$\approx 317$ \% (3 240 руб.), проректора И.Ю. Тимченко - меньше на $\approx 233 \%$ (4 420 руб.), профессора Л.И. Мандельштама - меньше на $\approx 230 \%$ (4 480 руб.), профессора Б.Н. Кандибы - меньше на $\approx 195$ \% (5 258 руб.), доцента К.С. Завриева - меньше на $\approx 267$ \% (3 860 руб.) [8, л. 74]. Такая ситуация сохранялась на протяжении всего учебного года [8, л. 80, 92].

По состоянию на июнь 1920 г. вместе с Ч.Д. Кларком также проживали его жена Надежда Аркадьевна Кларк - 53 года [11, л. 202], дочка Надина Кларк - 15 лет (родилась в 1905 г.) [11, л. 195], дочка ЕрикаМария Кларк - 16 лет (родилась 17 августа 1900 г.) [2, л. 189-192] и двое сыновей. В какой сфере деятельности были заняты дочери Ч.Д. Кларка на сегодня установить не удалось. Установлено, что оба сына профессора самостоятельно обеспечивали себя материально. Младший сын - Гарри Кларк, которому по состоянию на 22 июня 1920 г. было 14 лет в 1920/21 учебном году числился подручным рабочим в ОПИ [11, л. 194]. На этой должности он был утвержден протоколом Президиума ОПИ от 18 декабря 1920 г. [3, л. 52 об.-53]. Старший сын - Джон Кларк (родился 18 августа 1899 г.), названный в честь отца профессора, на протяжении трех лет жизни в Одессе занимал различные должности вспомогательного персонала в ОПИ: в 1918/19 учебном году - лаборант кафедры физики [12, л. 1 об., 5 об.], в 1919/20 учебном году - препаратор [34, л. 120], в весеннем семестре 1920 г. - помощник лаборанта кафедры физики с нагрузкой 24 часов в неделю [5, л. 11, 15], по состоянию на 16 июля 1920 г. помощник лаборанта $[11$, л. 145]. В ноябре и декабре 1919 г. Д.Ч. Кларк, равно как и другие его коллеги, получал «Кормовое довольствие», соответственно 1898 руб. 40 коп. и 2559 руб. 67 коп. [8, л. 87, 97]. С 18 июля 1921 г. Д.Ч. Кларк согласно его заявлению на имя ректора ОПИ был освобожден от должности препаратора физической лаборатории в связи с болезнью $[2$, л. 171, 186]. Данные о третьем сыне Ч.Д. Кларка и его судьба нам неизвестна. По непроверенным данным в 1919 г. один из его сыновей скончался и был похоронен на одесском кладбище [4]. На протяжении 1918-1922 гг. от голода и болезней в Одессе умирало большое количество людей. Многие жители города переносили тяжелые болезни. Например, в мае 1921 г. Ч.Д. Кларк вместе с женой находился на лечении в одной из одесских больниц [2, л. 169]. Доведенные политическими событиями последних лет до сложного материального положения представители высшей школы ради выживания вынуждены были распродавать за бесценок личные и домашние вещи, книги и т. п. Многие из них, не имея достаточных средств к существованию и минимальной квалифицированной медицинской помощи страдали от тяжелых болезней или умирали.

По своим убеждениям в послереволюционные годы Ч.Д. Кларк принадлежал к левой прогрессивной части академической корпорации. Данные политические взгляды формировались у него не только на основе общего непринятия идейных взглядов советской власти, но и сквозь 
призму частных взаимоотношений с большевиками, представители которых в местных органах власти, по всей видимости, враждебно относились к «буржуазному профессору». К общим факторам, которые, скорее всего, привели к не восприятию Ч.Д. Кларком большевиков были коммунистическая идеология, террор, военный коммунизм, коренизация (в ОПИ проявилась как украинизация) и другие методы установления их власти. Среди частных причин, по которым он не воспринимал советскую власть, по всей видимости, были лично Ч.Д. Кларком пережитые события в периоды установления в Одессе диктатуры пролетариата в 1919-1923 гг. Например, свидетельства репрессивной политики большевиков по отношению к его коллегам. Так, 16 июня 1919 г. в застенках Одесской губернской чрезвычайной комиссии был расстрелян (захоронен 29 августа) профессор, в 1907-1913 гг. ректор, Новороссийского университета С.В. Левашов [13, с. 184]. В ночь с 17 на 18 августа 1922 г. сотрудниками ГПУ УССР было арестовано 18 преподавателей высшей школы Одессы, 10 из которых на протяжении осени-зимы 1922-1923 гг. были высланы за границу (в анналах исторической науки эта акция получила название в виде идиомы - «философский пароход») [14-15]. В период пребывания большевиков в Одессе в 1919 г. их представители изъяли у Д.Ч. Кларка паспортную книжку [16, л. 120]. Эти и другие объективные и субъективные причины, скорее всего, оставили негативные воспоминания у Ч.Д. Кларка о советской власти и стали одними из аргументов того, чтобы ответить согласием на настойчивые приглашения руководства Латвийского университета возглавить кафедру судостроения механического факультета и реализовать свои изобретательские способности. После пятилетнего пребывания в Одессе в августе 1923 г. Ч.Д. Кларк с семьей уехал из СССР.

В качестве заключения отметим, что многогранная научно-педагогическая деятельность и интеллектуальное наследие Ч.Д. Кларка в «одесский» период его жизни длительное время оставались не изученными и не представленными в научной литературе по идеологическим соображениям. При разработке поставленных в статье задач широко использованы материалы архивов, часть которых была введена в научный оборот впервые.

К наиболее важным результатам достигнутым в статье можно отнести следующие: представлены педагогическая, научная и общественная деятельность Ч.Д. Кларка на историческом фоне 1918-1923 гг.; предпринята попытка реконструкции профессионального и творческого пути, заполнено некоторые лагуны в его биографии, а именно его вклад в организацию и институционализацию Одесского политехнического института; прослежено влияние общественно-политических, социальноэкономических и культурных факторов на «одесский» период жизни ученого; очерчены научно-творческое наследие профессора; учебно-методический и научно-технический потенциал Ч.Д. Кларка является весомой 
долей мирового интеллектуального наследия; исследованы его вклад в становление и развитие судостроения и судовой механики в Одессе и в целом в Украине, о чем свидетельствуют многочисленные разработки в этой области, которые проверены его многолетней профессиональной практикой.

Анализ профессиональной деятельности Ч.Д. Кларка в «одесский» период его жизни позволяет сделать вывод, что он удачно сочетал в себе талант незаурядного педагога, ученого, организатора образования и науки, инженера-изобретателя, общественного деятеля и порядочного гражданина. Глубокие знания, широкая эрудиция, большой творческий талант, преданность науке, навыки организатора и трудоспособность сочетались в нем с высокими моральными принципами, честностью и порядочностью, чувством долга и ответственностью за выполняемую работу, добротой, чутким и сердечным отношением к людям, что снискало ему глубокое уважение не только со стороны коллег, работавших с ним, а студентов и руководства.

Имя Ч.Д. Кларка как талантливого изобретателя и конструктора, виртуозного преподавателя и ученого, любимого не одним поколением студентов и коллег остается в памяти одесского научного сообщества долгие годы. Ч.Д. Кларк - выдающаяся личность, мировой ученый в области судостроения, профессор, организатор преподавания судостроения и судовой механики в Одессе и других городах Европы.

\section{Служебная записка председателя}

Приложение 1

\section{Одесского отделения Всеукраинского комитета содействия ученым Ч.Д. Кларка от 30 октября 1922 г. [17, л. 134-134 об.]}

В Всеукраинский комитет содействия ученым

Одесское отделение Всеукраинского комитета содействия ученым сим извещает, что им получено три миллиарда рублей переводом на Госбанк, причем сообщает, что настоящая сумма весьма незначительна, так как деятельность Комитета значительно расширилась и потребность в средствах велика. В настоящее время Одесское отделение имеет в своем распоряжении «Дом отдыха» для ученых, «Дом ученых» и при «Доме ученых» лавку-распределитель академиков, а также пекарню для выпечки хлеба академикам. При «Доме ученых» имеется общежитие для одиноких профессоров и преподавателей высшей школы. На оборудование «Дома Ученых» затрачены значительные средства. Одесское отделение изыскивает средства на месте, но все же требуются денежные средства из центра, чтобы все начатое Комитетом поддерживать на должной высоте. Смета на октябрь месяц на все нужды Комитета были своевременно посланы.

Одесское Отделение получило всю задолженность по академпайку с января по октябрь месяц и наряд на октябрь и ноябрь месяцы по 742 
академпайка на каждый месяц, но остается открытым вопрос, как распределить 742 пайка между всеми лицами, получающими академпаек. Ждем разъяснения телеграммы и указания. На октябрь месяц зачислено, согласно постановлению Комиссии академпайка при Научном Бюро, 748 лиц с 1549 семейных пайков.

Одесское Отделение прилагает все меры к тому, чтобы удешевить жизнь академиков и с этой целью обратилось в государственные и общественные учреждения г. Одессы с просьбой отпускать товары Комитету на льготных условиях и по дешевым ценам. Многие учреждения идут на встречу Комитету, но за наличный расчет. Есть возможность получать дешево необходимые продукты через Внешторг, но чтобы удешевить их стоимость для этого требуется снятие пошлины таможни, а по сему Одесское отделение настоятельно просит Всеукраинский комитет содействия ученым принять все меры в таможенном округе к освобождению от пошлины тех товаров, которые будут отпускаться Внешторгом Комитету. Распоряжения таможенного округа сообщить Одесской таможне.

Настоятельная просьба об отпуске топлива и керосина для академиков. Прошлогоднее распоряжение об отпуске дров и керосина далеко не выполнено полностью.

Помимо просимых средств на содержание «Дома отдыха» и «Дома Ученых», необходимы средства для выдачи пособий в случаях острой нуждаемости. Комитет ежемесячно выплачивает по 50 миллионов рублей тем профессорам, которые из-за преклонности лет вышли за штат (профессорам Занчевскому, Зеленецкому, Панченко и Федорову).

Как обстоит дело с академобеспечением и с квартирной анкетой?

Обращаясь с вышеуказанными просьбами, Одесское Отделение просит обратить внимание на нужды его Отделения и отпускать ежемесячно необходимые суммы согласно присланной сметы, а также прислать 15 миллиардов рублей /как обратный капитал/ для закупки товаров в государственных и общественных учреждениях на льготных условиях.

Председатель Чарльз Джонович Кларк [подпись]

Ответственный секретарь [подпись]

Приложение 2

Докладная записка председателя

Одесского отделения Всеукраинского комитета содействия ученым

Ч.Д. Кларка за 1922 г. [17, л. 135-136]

Докладная Записка

Началом деятельности Одесского отделения Всеукраинского комитета содействия ученым, заменившего прежде существовавшую Междуведомственную комиссию по оказанию помощи ученым г. Одессы, 
следует считать 27-го декабря 1921 г., когда состоялась под председательством тов. Потемкина организационное заседание, на котором были поставлены ряд определенных задач и намечен план работ Комитета. $\mathrm{C}$ тех пор Комитет беспрерывно работает для улучшения положения быта ученых г. Одесса, все более и более расширяя круг своей деятельности, оказывая посильную помощь научным работникам в их нуждах.

В первое время своего существования Комитет вынужден был ограничивать свою деятельность раздачей денежных пособий особо нуждающимся лицам, распределением академпайков и урегулированием через существующую при Комитете хозяйственную комиссию получения и раздачи академпайка, который выдавался до того времени распределителями «ОПО», а затем «Опродкомгуба» не достаточно регулярно и не в полном объеме.

В апреле месяце у Комитета явилась возможность еще и иным образом помочь «академикам». Из Харькова получена была первая партия мануфактуры, обуви, шапок, перчаток, носков, валенок, посуды и проч., которая была распределена между институтами бесплатно. В это же время было прислано дополнительное академобеспечение в размере 137520 рублей (деньзн[аки] [19]22 года), которые за неимением соответственных инструкций из центра было распределено пропорционально количеству пайков, лицам получающим академпаек.

В связи с поездкой секретаря Комитета в г. Харьков, когда была установлена живая связь с центром, получены были соответствующие инструкции, определенные директивы работы, а также существованная материальная и денежная поддержка, направление и темп работы Комитета изменялись.

Особое внимание было обращено на устройство «Дома», где люди науки могли бы укрепить свои силы для продолжения ученой деятельности. В результате хлопот перед Губисполкомом, Курортным управлением, Губздравом и др[угими] местными органами создан был «Дом отдыха» (о «Доме отдыха» была представлена докладная записка), где в продолжении 2 1/2 месяцев 40 ученных пользовались отдыхом, состоя на полном довольствии Комитета. В настоящее время здание «Дома отдыха» и весь инвентарь закреплены за Комитетом и подготовлены к будущему весеннему и летнему сезону.

Параллельно с этим была произведена раздача во второй раз дополнительного академобеспечения (на этот раз строго сообразуясь с инструкциями, полученными из центра). Распределено было 137520 рублей (деньзн[аки] [19]22 г.), при чем золотой рубль составлял около 40 рублей (деньзн[аки] [19]22 г.). Была роздана мануфактура (1 520 аршин), привезенная из центра, за деньги в счет жалования преподавателям высшей школы.

С наступлением осени начался 3-й период деятельности Комитета, когда центром внимания стал открываемый ныне «Дом ученых», с обще- 
житием для одиноких и столовой. Большой ремонт помещения дома в настоящее время закончен (затрачено 284222 руб.) (деньзн[аки] [19]22 г.) и только отсутствие необходимых средств тормозит открытие «Дома ученых». Необходимо приобрести посуду, топливо и проч. - мебель и внутреннее оборудование имеетя. При «Доме ученых» имеется лавка распределитель академпайка, где проведена спешная работа по распределению задолженности по академпайку за январь-сентябрь м[еся]цы в следующем количестве:

Муки ржаной 2162 пуда,

Масла подсолнечного 265 пудов,

Мяса 925 пудов,

Крупы 104 пуда.

В настоящее время производится раздача 742 пайка за сентябрь и ноябрь м[еся]цы, а также свозятся к распределению продукты на 209 пайков (185 дополнительных пайков для Одессы, которые будут в ближайшее время распределены дополнительно и 24 пайка для г[ородов] Херсона и Николаева.

Параллельно с раздачей академпайка в лавке производится продажа академикам по дешевым, значительно ниже рыночных, ценам ряды продуктов, полученных в трестах, госфабриках и других учреждениях и не входящих, не смотря ни на их крайнюю необходимость, в наряд по академпайку.

При лавке имеется соответственная, вполне оборудованная пекарня, где для лиц, желающих получить паек не мукой, а хлебом выпекается хлеб собственными средствами под контрольным хозяйственной комиссии при комитете.

В настоящее время такое произведена раздача дополнительных академпайков по категориям: из пока полученных 2812055 рублей (деньзн[аки] [19]22 г.) - 5 \% удержаны в фонд комитета, а остальные розданы академикам I-V категориям, при чем каждое лицо, зачисленное в І-ю категорию получило 3935 рублей, во II-ю - 5902 руб[ля], в III 9837 р[ублей], в IV - 19675 рубл[ей], и в V - 39350 рубл[ей].

Кроме указанных V-ти категорий установлено Комитетом еще нулевая категория лиц, получающих только академпаек /по одному пайку/, не имеющих научных заслуг, необходимых для зачисления в высшую категорию, но заслуживающих по мнению Комитета поддержки.

Подробный отчет о деятельности Комитета за текущий 1922 год и денежный отчет будет прислан по окончанию 1922 года.

Председатель Чарльз Джонович Кларк [подпись]

Ответственный секретарь [подпись] 


\section{СПИСОК ЛІТЕРАТУРИ}

1. ГАOО, ф. P-126, on. 1, д. 142.

2. ГАOO, ф. P-126, on. $1, \partial .143$.

3. ГАОО, ф. P-126, on. $1, \partial .112$.

4. Кларк Чарльз Джсонович: 31.05.1867-03.06.1942. Государственные награды и почетные звания // Ресурс доступа: http://kzref.org/klark-charlez-djonovich-31-05-186703-06-1942gosudarstvennie-n.html.

5. ГАOO, ф. P-126, on. 1, д. 107.

6. ГАOO, ф. P-126, on. 1, d. 4.

7. ГАOO, ф. P-126, on. $1, \partial .10$.

8. ГАOO, ф. P-126, on. 1, д. 16.

9. ГАOO, ф. P-126, on. $1, \partial .102$.

10. ГАОО, ф. P-126, on. 1, d. 15.

11. ГАОО, ф. P-126, on. 1, d. 114.

12. ГАOO, ф. P-126, on. 1, d. 11.

13. Левченко В.В., Левченко Г.С. Александро-Невская иерковь Новороссийского университета: история, персоналии, документы. Изд. 2-е, перевед. на русс. язык, испр. и дополн. Одесса: Бондаренко М.О., 2016. 396 с.

14. Левченко В.В. Одесские ученые - пассажиры «философского парохода»: к истории высылки интеллигенции в 1922 г. // Юго-Запад. Одессика. Историко-краеведческий научный альманах. Bыn. 5. Одесса, 2008. C. 162-182.

15. Левченко В.В. «Активный противник Соввласти...»: до історії висилки одеських вчених із країни 1922 р. // 3 архівів ВУЧКГПУ-НКВД-КГБ. Київ-Харків, 2012. № 1 (38). С. 7-24.

16. ГАОО, ф. P-126, on. 1, д. 556.

17. ЦГАВОВ, ф. 331 , on. $1, \partial .35$.

\section{REFERENCES}

1. Klark, CHarl'z Dzhonovich: 31.05.1867-03.06.1942. Gosudarstvennye nagrady $i$ pochetnye zvaniya. Access resource: http:// kzref.org/klark-charlez-djonovich-31-05-186703-06-1942gosudarstvennie-n.html.

2. Levchenko, V.V., Levchenko, G.S. (2016) Aleksandro-Nevskaya cerkov' Novorossijskogo universiteta: istoriya, personalii, dokumenty. Izd. 2-e, pereved. na russ. yazyk, ispr. i dopoln. Odessa: Bondarenko M.O. (in Russian). 
ВІСНИК

ОДЕСЬКОГО НАЦІОНАЛЬНОГО

МОРСЬКОГО УНІВЕРСИТЕТУ

№ 3 (63), 2020
HERALD

OF THE ODESSA NATIONAL

MARITIME UNIVERSITY

№ 3 (63), 2020

3. Levchenko, V.V. (2008) Odesskie uchenye-passazhiry «filosofskogo parohoda»: $k$ istorii vysylki intelligencii v 1922 g. YUgo-Zapad. Odessika. Istoriko-kraevedcheskij nauchnyj al'manah. Vyp. 5. Odessa, pp. 162-182.

4. Levchenko, V.V. (2012) "Aktivnyj protivnik Sovvlasti...»: do istorii visilki odes'kih vchenih iz krä̈ni 1922 r. Z arhiviv VUCHK-GPUNKVD-KGB. Kï̈-Harkiv, № 1 (38), pp. 7-24.

Стаття надійшла до редакиії 24.01.2020

Посилання на статтю: Левченко В.В., Левченко Г.С., Ляшенко А.Б. Перипетии судьбы профессора Чарльза Кларка: к истории «Одесского» периода жизни. Ч.2 // Вісник Одеського національного морського університету: Зб. наук. праць, 2020. № 3 (63). С. 5-20 DOI 10.47049/2226-1893-2020-3-5-20.

Article received 24.01.2020

Reference a JournalArtic: Levchenko V., Levchenko G., Lyashenko A. The peripeties of professor Charles Clark: to the history of the «Odessa» period of life // Herald of the Odessa national maritime university. 2020. 3(63), 5-20. DOI $10.47049 / 2226-1893-2020-3-5-20$. 